\title{
CAMK2B Gene
}

National Cancer Institute

\section{Source}

National Cancer Institute. CAMK2B Gene. NCI Thesaurus. Code C104830.

This gene plays a role in calcium signaling. 